\title{
Primary Structure Analysis of Antifungal Peptides from Cultivated and Wild Cereals
}

\author{
Eugene Rogozhin ${ }^{1,2 * * \mathbb{D}}$, Dmitry Ryazantsev ${ }^{1}$, Alexey Smirnov ${ }^{3}$ and Sergey Zavriev ${ }^{1}$ \\ 1 Shemyakin and Ovchinnikov Institute of Bioorganic Chemistry, Russian Academy of Sciences, \\ ul. Miklukho-Maklaya 16/10, 117997 Moscow, Russia; d.yu.ryazantsev@gmail.com (D.R.); \\ szavriev@ibch.ru (S.Z.) \\ 2 Gause Institute of New Antibiotics, ul. Bolshaya Pirogovskaya, 11, 119021 Moscow, Russia \\ 3 Department of Plant Protection Timiryazev Russian Agricultural University, ul. Timiryazevskaya 49, \\ 127550 Moscow, Russia; smirnov@timacad.ru \\ * Correspondence: rea21@list.ru; Tel.: +7-495-336-40-22
}

Received: 14 July 2018; Accepted: 6 September 2018; Published: 12 September 2018

\begin{abstract}
Cereal-derived bioactive peptides with antimicrobial activity have been poorly explored compared to those from dicotyledonous plants. Furthermore, there are a few reports addressing the structural differences between antimicrobial peptides (AMPs) from cultivated and wild cereals, which may shed light on significant varieties in the range and level of their antimicrobial activity. We performed a primary structure analysis of some antimicrobial peptides from wild and cultivated cereals to find out the features that are associated with the much higher antimicrobial resistance characteristic of wild plants. In this review, we identified and analyzed the main parameters determining significant antifungal activity. They relate to a high variability level in the sequences of C-terminal fragments and a high content of hydrophobic amino acid residues in the biologically active defensins in wild cereals, in contrast to AMPs from cultivated forms that usually exhibit weak, if any, activity. We analyzed the similarity of various physicochemical parameters between thionins and defensins. The presence of a high divergence on a fixed part of any polypeptide that is close to defensins could be a determining factor. For all of the currently known hevein-like peptides of cereals, we can say that the determining factor in this regard is the structure of the chitin-binding domain, and in particular, amino acid residues that are not directly involved in intermolecular interaction with chitin. The analysis of amino acid sequences of alpha-hairpinins (hairpin-like peptides) demonstrated much higher antifungal activity and more specificity of the peptides from wild cereals compared with those from wheat and corn, which may be associated with the presence of a mini cluster of positively charged amino acid residues. In addition, at least one hydrophobic residue may be responsible for binding to the components of fungal cell membranes.
\end{abstract}

Keywords: antimicrobial peptides; wild and cultivated cereals; primary structure analysis; biological activity

\section{Introduction}

Defense peptides, including antimicrobial peptides, are essential components of plant innate immunity and occur in all of the described species from the botanical families of flowering plants. Numerous research papers devoted to antimicrobial proteins and peptides from gymnosperm plants have demonstrated the so-called evolutionary succession and antiquity of these defense molecules in the plant kingdom. The overwhelming majority of wild flowering species (dicotyledonous and monocotyledonous) grow in unfavorable conditions (e.g., sunlight, availability of mineral sources, soil fertility, optimal acidity, etc.). At the molecular level, this usually results in allelopathic interactions 
between plants cohabitants [1,2]. For example, more "aggressive" wild plant species can be more successful through the synthesis of metabolites suppressing the growth and development of other plant species. These substances can be actively secreted by the root system to soil or by aerial vegetative parts (leaves, stems, and flowers).

High resistance to biotic and abiotic environmental stress factors is vital to plants. Many of these plants (in particular, cereals) grow in high-salinity soils [3,4]. For instance, lyme grass (Leymus arenarius) is an endemic species that is widespread in the northern parts of Russia, and lives in acidic soils along the coastlines of the White and Barents seas, including littoral areas with low mean air temperatures [5,6]. Elongated couch grass (Elytrigia elongata) is resistant to extremely high concentrations of organic and inorganic salts in soil, but grows in alkaline soils with high air temperatures $[7,8]$. In some cases, there are little or no data about the influence of some biotic stress factor on wild plants, which include microorganism infections and damage by pests, nematodes, or other invertebrates. The reason is a lack of economic relevance in agriculture. A few exceptions are the wild relatives of cultivated plants, such as cereals and leguminous breeds and hybrids, which may potentially be used to create novel breeds with high resistance to diseases.

Disease agents and pests that have economic significance for several cultivated cereals (soft and durum wheat, rye, barley, rice, etc.) are under intensive study. Methods to suppress pathogenecity and related damage have been developed and optimized based on a combination of agrotechnical, chemical, and biological approaches. Defense polypeptides are present in all types of flowering plants, but differences may occur in some plant organs at different stages of plant ontogenesis. In this work, a comparative structural analysis of antimicrobial peptides (AMPs) was conducted. AMPs were qualitatively and quantitatively characterized in the kernels of wild and cultivated cereals to identify any differences in their amino acid sequences [9-12]. The study purpose was to gain further understanding of the contribution of this direction of innate immunity to the greater tolerance of wild plants compared to that of cultivated plants.

Defensins, hevein-like peptides, thionins, and alpha-hairpinins (hairpin-like peptides) were investigated. We found that these AMPs were involved in the defense reaction of innate and adapted plant immunity. Thus, the defensin and thionin families are "pathogenesis-related proteins" (PR-proteins) $[13,14]$. For hevein-like and hairpin-like peptides, a reliable increase in the transcription level of their encoding genes in response to abiotic or biotic stress factors was identified by semi-quantitative PCR amplification $[15,16]$.

\section{Comparative Analysis of the Primary Structure of Defensins Isolated from Wild and Cultivated Cereals}

Defensins are defense peptides isolated from numerous angiosperm plants [17-27], Ginkgoaceae [28], and some coniferous species (Pinophyta) [29]. Initially, defensins isolated from wheat and barley kernels were assigned to the thionin subfamily ( $\gamma$-thionins) [30,31]; however, they were demonstrated to have a homology with defensins from mammals and insects, which was the reason to consider these defensins as a new family [31,32].

Plant defensins are the most highly expressed defense molecules in plant immunity. As in animal immunity, they can be functionally activated in response to any phytopathogenic microorganisms (fungi, bacteria, oomycetes, etc.). These molecules typically have a rather wide spectrum of biological activity, although their main function is the interaction with the cell membrane of a target cell, followed by permeabilization, disruption of the transmembrane electrochemical potential, deprivation of essential metabolites, and, finally, cell death [33-35].

There are defensins whose number is limited to one or two per cereal species (wheat, rye, barley, sorghum, and millet). Thus, we investigated the peptidomic composition of hexaploid wheat (Triticum kiharae) kernels using protein chemistry techniques. We also isolated and structurally characterized two defensin subfamilies. The first group was the well-known gamma-thionin family (originally D-defensins). The second group was the "omega-type" family that is characterized by a novel structural 
motif differing from the traditional cysteine-stabilized $\alpha \beta$-motif by the position of cysteine residues in the polypeptide chain [36]. AMPs from this group were identified in multigenomic wheat species and wild cereals [37].

Barnyard grass (Echinochloa crusgalli) is well-characterized in terms of its defense peptide composition. Using a combination of acidic extraction and several types of liquid chromatography, two high homologous defensins (Ec-AMP-D1 and Ec-AMP-D2) with a single amino acid substitution were isolated (Ala46His) [32]. Notably, a similar "pair" of defensins containing single substitution was discovered in several dicotyledonous plant species. The two most notable features are the presence of a variable amino acid substitution in the loop fragment of molecules, which is critical for the spatial orientation, and a quantitative level of the antimicrobial activity. Both defensins were tested against a broad spectrum of plant pathogenic fungi from Fusarium (F. graminearum, F. oxysporum, F. verticillioides), Bipolaris sorokiniana, Phoma betae, Botrytis cinerea, some specific pathogens of corn (Zea mays) (Colletotrichum graminicola, Diplodia maydis), and oomycetes (Pythium debarianum and Phytophthora infestans) at concentrations ranging from $1.7 \mu \mathrm{M}$ to $20 \mu \mathrm{M}$. In all of the cases, the D1 molecule was more active than D2. Importantly, these peptides could cause the morphological destruction of conidia and mycelium in oomycetes, but not in fungi [38].

On the basis of multiple alignments of well-known amino acid sequences of defensins, we may conclude that the primary structure homology is typical of cultivated and wild species (usually, $55-70 \%$ of homology). However, the key factor determining the significant antimicrobial activity (primarily antifungal) of wild cereals is related to a high variability of C-terminal fragments and a high percentage of hydrophobic amino acid residues in their biologically active defensins.

AMPs from cultivated forms usually exhibit weak or no activity. Plant defensins from dicots and monocots are cationic amphiphilic polypeptides, and their positive charge is primarily localized in the $\mathrm{N}$-terminal part of a molecule, and initiates the interaction with negatively charged components of bacteria and cell walls of fungi and oomycetes (Figures 1 and 2, the plant defensin sequences from the literature performed UniProt/SwissProt algorithms to generate the alignments via CLUSTAL OMEGA interactive service (https://www.ebi.ac.uk/Tools/msa/clustalo/). As illustrated on the phylogenetic tree, all of the molecules from seven different branches, most of them combining purely very high homologous sequences, as a rule, are isolated from one plant species. To date, some defensins from cultivated cereals (wheat, barley, sorghum, and corn), which are a unique group of molecules participating in plant immunity, have been studied, but these have exhibited a low level of antimicrobial activity (20 $\mu \mathrm{M}$ to $100 \mu \mathrm{M})$ [33]. Defensins from cereal barnyard grass (E. crusgalli) from the Poaceae family also, in contrast to previously studied wild plants, demonstrate significant antifungal activity against plant pathogenic micromycetes and oomycetes [39]. It is typical, as they are localized on various branches on phylogenetic tree (Figure 2), but this correlation is not expressed, which is similar to the defensins from dicots.

The discovered differences are a striking example of the biological activity preservation of defensins from wild plant forms to achieve suitability, competitive ability, and adaptation in biocenoses, which were previously lost in the breeding process. Concerning defensins from other plant species, highly homologous AMPs (RsAFP1 and RsAFP2) differing by two amino acid substitutions were isolated from radish (Raphanus sativus L.) seeds [39,40]. These substitutions were localized in the $\beta 1$-helical and $\alpha$-helical regions, respectively, and led to the accumulation of a higher total positive charge in the Rs-AFP2 peptide compared to that in Rs-AFP1, and to higher antimicrobial activity against a model fungal species, Fusarium culmorum [40]. At the same time, the site-directed mutagenesis of Rs-AFP2 based on the addition of arginine residues led to an increase in the antifungal activity of a mutant molecule relative to its native form. These results are in accordance with the data obtained for Ec-AMP-D1/D2 [38]. 

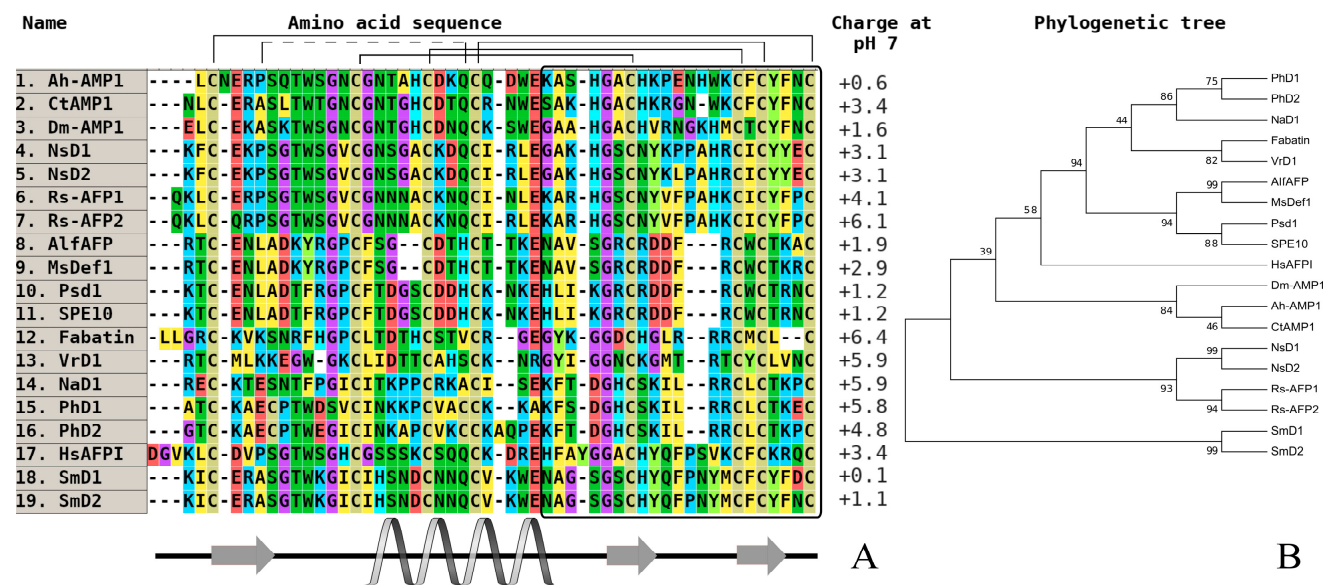

Figure 1. The alignment (A) and phylogenetic tree (B) of defensins from dicots. Amino acids are highlighted in color, and conserved disulfide bonds are connected by black lines. The variable C-end is marked with a black rectangle. Conservative elements of the secondary structure are shown under the alignment in accordance with RsAFP1 from radish (Raphanus sativus) seeds [29]. Ah-AMP1—defensin from Aesculus hippocastanum (GenBank ID: AAB34970); CtAMP1—defensin from Clitoria ternatea (GenBank ID: Q7M1F2); DmAMP1—defensin from Dahlia merckii (GenBank ID: P0C8Y4); NsD1—defensin D1 from Nigella sativa (UniProt ID: P86972); NsD2—defensin D2 from N. sativa (UniProt ID: P86973); Sm-D1—defensin D1 from Stellaria media (GenBank ID: C0HL82); Sm-D2—defensin D2 from S. media (GenBank ID: C0HL83); Rs-AFP1—antifungal protein 1 from Raphanus sativus (GenBank ID: AAB22709); Rs-AFP2-antifungal protein 2 from R. sativus (GenBank ID: AAB22710); AlfAFP—antifungal peptide from Medicago sativa (GenBank ID: AAG40321); MsDef1-defensin 1 from M. sativa (GenBank ID: AAV85433); Psd1-defensin 1 from Pisum sativum (UniProt ID: P81929); SPE10—defensin from Pachyrhizus erosus (GenBank ID: AAT80338); Fabatin—defensin from P. erosus (GenBank ID: ACI02057); VrD1—defensin from Vigna radiata (GenBank ID: AAR08912); NaD1—defensin from Nicotiana alata (GenBank ID: Q8GTM0); PhD1—defensin 1 from Petunia hybrida (GenBank ID: Q8H6Q1); PhD2—defensin 2 from P. hybrida (GenBank ID: Q8H6Q0); Hs-AFP1—defensin 1 from Heuchera sanguinea (GenBank ID: AAB34974).
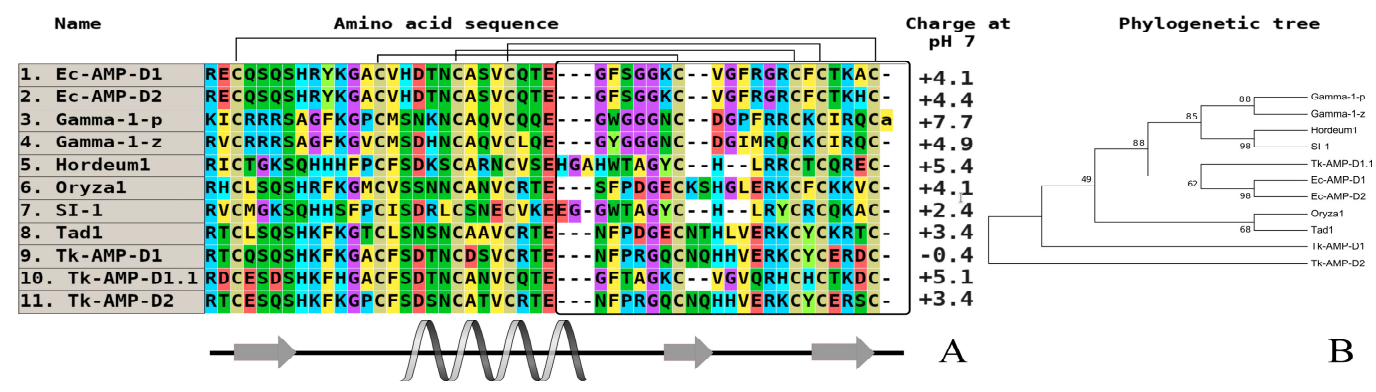

Figure 2. The alignment (A) and phylogenetic tree (B) of defensins from wild and cultivated cereals (monocots). Amino acids are highlighted in color, and conserved disulfide bonds are connected by black lines. The variable $\mathrm{C}$-end is marked with a black rectangle. Conservative elements of the secondary structure are shown under the alignment according to gamma-purothionin from soft wheat (T. aestivum) (Gamma-1-p) (CP) [40]. Ec-AMP-D1—defensin 1 from Echinochloa crusgalli (UniProt ID: P86518) (WP); Ec-AMP-D2—defensin 2 from E. crusgalli (UniProt ID: P86519) (WP); Gamma-1-p-defensin (Gamma-1-purothionin) from Triticum aestivum (UniProt ID: P20158) (CP); Gamma-1-z-defensin (Gamma-zeathionin-1) from Zea mays (UniProt ID: P81008) (CP); Oryza1—defensin from Oryza sativa Japonica Group (GenBank ID: BAD23741) (CP); Tad1—defensin (Gamma-thionin) from T. aestivum (GenBank ID: BAC10287) (CP); Tk-AMP-D1—defensin 1 from Triticum kiharae (UniProt ID: P84963) (CP); Tk-AMP-D2—defensin 2 from T. kiharae (UniProt ID: P84968) (CP); Tk-AMP-D1.1—defensin 1.1 from T. kiharae (UniProt ID: P84965) (CP). All structures are marked: CP_cultivated plant species, $\mathrm{WP}$ - wild plant species. 
It should be noted that so far, some defensins of cultivated cereals (wheat, barley, sorghum, and corn) have been studied. Defensins are the unique group of molecules that are involved in the protection of these plants from fungal diseases [41]. The results obtained in our investigations confirm the existing literature data on the study of grain defensins [42], and show that wheat defensins (T. kiharae) (synthetic hexaploid, which is obtained by crossing the wild species of Triticum timopheevii and Aegilops squarrosa aegilops) have an insignificant antifungal activity against several phytopathogenic filament fungi. We show in this review that defensins isolated from wild-growing plant-barnyard grass (E. crusgalli), which also belongs to the Cereals family (Poaceae), in contrast to the previously studied wild forms of plants, show significant antifungal activity against a number of phytopathogenic fungi and oomycetes. The detected differences are a good example of the preservation of antifungal activity in the defensins of wild cereals for the achievement of fitness, competitiveness, and adaptation in biocenoses; those capabilities are mostly lost in the process of cultivation. The detection of antifungal activity of Echinochloa defensins opens new possibilities for the analysis of structural-functional relationships, including in particular the identification of residues, which are determinants of biological activity. Basically, this can be achieved in three ways: by comparing the amino acid sequences of highly homologous plant peptides of different phylogenetic remoteness or from closely related plants that are highly contrasting in biological (antifungal) activity; by conducting a site-directed mutagenesis of structures of active peptides; and by the construction of chimeric molecules combining different parts of peptide structures differing in their activity (strong or weak).

It should be also noted that due to a wide spread of massively parallel transcriptome sequencing in the last years, a lot of genes encoding defensin-like peptides have been discovered in many plants, including cereals [43-47]. These genes are able to be expressed after the creation of biologically active molecules on different stages of plant ontogeny in normal or stress conditions.

\section{Investigation of Structural Determinants of Other AMPs (Thionins, Hevein-Like Peptides, and Alpha-Hairpinins), Which Provide Higher Antifungal Activity to Wild Cereals}

Thionins are structurally similar to plant defensins. A principal difference between them is the presence of a single alpha-helix as an element of the secondary structure in defensins. They contain a cluster of two antiparallel alpha-helices that are coupled by a beta-turn, and are localized in vacuoles [48].

Although thionins are the first discovered and described AMP family from plants, the number of isolated and characterized thionins is lower compared to that in the defensin family $[49,50]$. The basic members in cereals and all other plants are the alpha and beta-purothionins isolated from the kernels of soft wheat (Triticum aestivum). Their three-dimensional structures were determined using X-ray diffraction [51-54]. Subsequently, thionins from other cultivated cereals were isolated and characterized in detail (hordothionins from barley (Hordeum vulgare), zeathionins from corn (Zea mays), and avesins from rice (Oryza sativa)) [24,55-57]. An interesting peculiarity of thionins is a higher total positive charge at neutral $\mathrm{pH}$ as well as significant membrane-active features that can impart cytotoxic effects toward some tumor cell lines in vitro. Their influence on the expression level of oncogenes, tumor suppressor genes [58-60], and ability to bind DNA can also decrease the toxic effect of heavy metal ions [61]. These properties are also found in thionins from wild dicots [62-66]. These molecules belong to the eight-cysteine thionin subfamily. There is another subfamily with six-cysteine type thionins isolated from white mistletoe (Viscum album), which are called viscotoxins $[67,68]$. The antimicrobial activity of these peptides was determined against Gram-positive and Gram-negative bacteria, yeasts, fungi, and oomycetes at an $\mathrm{IC}_{50}$ concentration of $1-15 \mu \mathrm{g} / \mathrm{mL}$ (Table 1) [69]. It is typical that there is quite determined divergence between the eight and six-cysteine-containing thionins, which is expressed their localization in different branches of the built phylogenetic tree. 
Table 1. Antifungal activity of some known thionins isolated from cereals $\left(\mathrm{IC}_{50}, \mu \mathrm{M}\right)$.

\begin{tabular}{|c|c|c|c|c|c|c|c|}
\hline Peptide/Microbe & $\begin{array}{c}\alpha 1 \\
\text {-Purothionin }\end{array}$ & $\stackrel{\alpha}{\alpha}$-Hordothionin & $\frac{\gamma}{-1-H-H o r d o t h i o n i n}$ & $\frac{\gamma}{\text {-1-P-Purothionin }}$ & $\begin{array}{c}\gamma \\
\text {-1-Zeathionin }\end{array}$ & Tk-AMP-BP1 & Tk-AMP-BP2 \\
\hline Bipolaris sorokiniana & 3.2 & 5.0 & Not tested & Not tested & Not tested & 5.6 & 32.0 \\
\hline Botrytis cinerea & Not tested & 20.0 & Not tested & Not tested & Not tested & Not tested & 32.0 \\
\hline F. solani & Not tested & 5.0 & Not tested & Not tested & Not tested & Not tested & Not tested \\
\hline F. verticillioides & 1.9 & 2.7 & 2.2 & 3.5 & 3.0 & 4.5 & Not tested \\
\hline Neurospora crassa & Not tested & 10.0 & Not tested & Not tested & Not tested & Not tested & Not tested \\
\hline
\end{tabular}

A comparative analysis of amino acid sequences isolated from the main species of wild cereals did not achieve positive results. For example, we could not predict any structure-function relationship between members of this family in cultivated cereals or wild plants. However, if we consider the similarity of some estimated physicochemical parameters (charge, localization of secondary structure elements) between thionins (Figure 3) and defensins (Figures 1 and 2), the presence of high divergence on a fixed part of any polypeptide (e.g., C-terminus) may be a key factor.

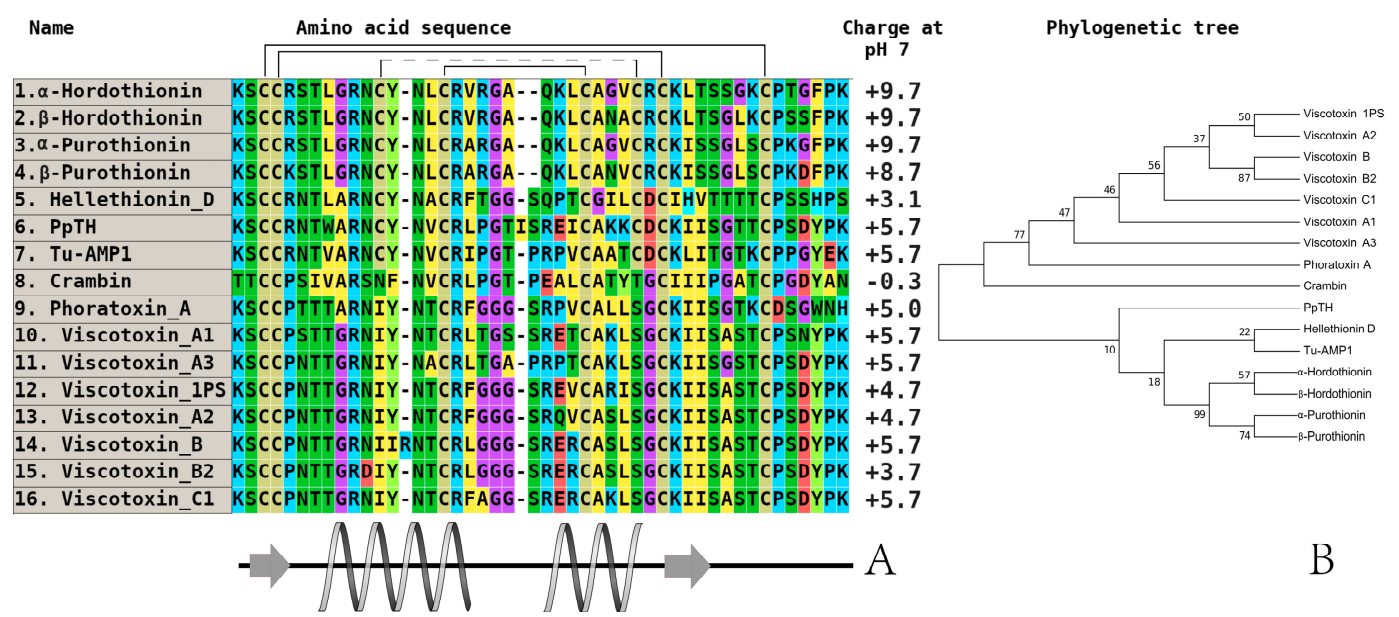

Figure 3. The alignment (A) and phylogenetic tree (B) of plant thionins from eight and six-cysteine type subfamilies. Amino acids are highlighted in color, and conserved disulfide bonds are connected by black lines. Conservative elements of the secondary structure are shown under the alignment according to alpha-purothionin from soft wheat (T. aestivum), (CP) [57]. $\alpha$-hordothionin-thionin from Hordeum vulgare (monocotyledons, UniProt ID: P01545), (CP); $\beta$-hordothionin-thionin from H. vulgare (UniProt ID: P21742), (CP); $\alpha$-purothionin-thionin from Triticum aestivum (monocotyledons, GenBank ID: AFQ60540), (CP); $\beta$-purothionin—thionin from T. aestivum (AAB71137), (CP); hellethionin_D—thionin from Helleborus purpurascens (dicotyledons, UniProt ID: P60057), (WP); PpTH-thionin from Pyrularia pubera (dicotyledons, UniProt ID: P07504), (WP); Tu-AMP1-thionin from Tulipa gesneriana, (monocotyledons, [22]), (CP); crambin-thionin from Crambe hispanica subsp. abyssinica (dicotyledons, UniProt ID: P01542), (WP); phoratoxin_A—thionin from Phoradendron leucarpum subsp. tomentosum (dicotyledons, UniProt ID: P01539), (CP); viscotoxin_A1—thionin from Viscum album (dicotyledons, GenBank ID: 3C8P_B), (WP); viscotoxin_A3—thionin from V. album (GenBank ID: VTVAA3), (WP); viscotoxin_1PS—thionin from V. album (UniProt ID: P01537), (WP); viscotoxin_A2—thionin from V. album (UniProt ID: P32880), (WP); viscotoxin_B—thionin from V. album (UniProt ID: P08943), (WP); viscotoxin_B2-thionin from V.album (UniProt ID: P08943), (WP); viscotoxin_C1-thionin from V.album (UniProt ID: P83554), (WP). All structures are marked: $\mathrm{CP}$-cultivated plant species, WP-wild plant species.

Hevein-like AMPs possess structural homology with hevein, the first real chitin-binding peptide isolated from Hevea brasiliensis [70]. Apart from hevein, lectins, chitinases from I/IV classes, and hevein-like AMPs belong to chitin-binding polypeptides [71,72]. 
The real revelation occurred when a novel structural type of hevein-like antimicrobial peptides with a 10-cysteine motif was isolated from the kernels of wheat (T. kiharae). Curiously, only for cultivated cereals were these peptides obtained first. It allowed a reconsideration of the modern classification of hevein AMPs to diverge them into two subfamilies: six-cysteine-containing peptides, such as peptides from amaranth (Amaranthus caudatus, A. retroflexus) [73-75], common chickweed (Stellaria media) [76,77], and 10-cysteine-containing peptides [78,79]. The most famous examples are wheat antimicrobial peptides (WAMPs) from T. kiharae and lyme grass antimicrobial peptides (LAMP) from L. arenarius families $[80,81]$. To date, in addition to wheat, a similar homologue was also isolated and characterized from the wild cereal lyme grass (L. arenarius) (Figure 4) [81].
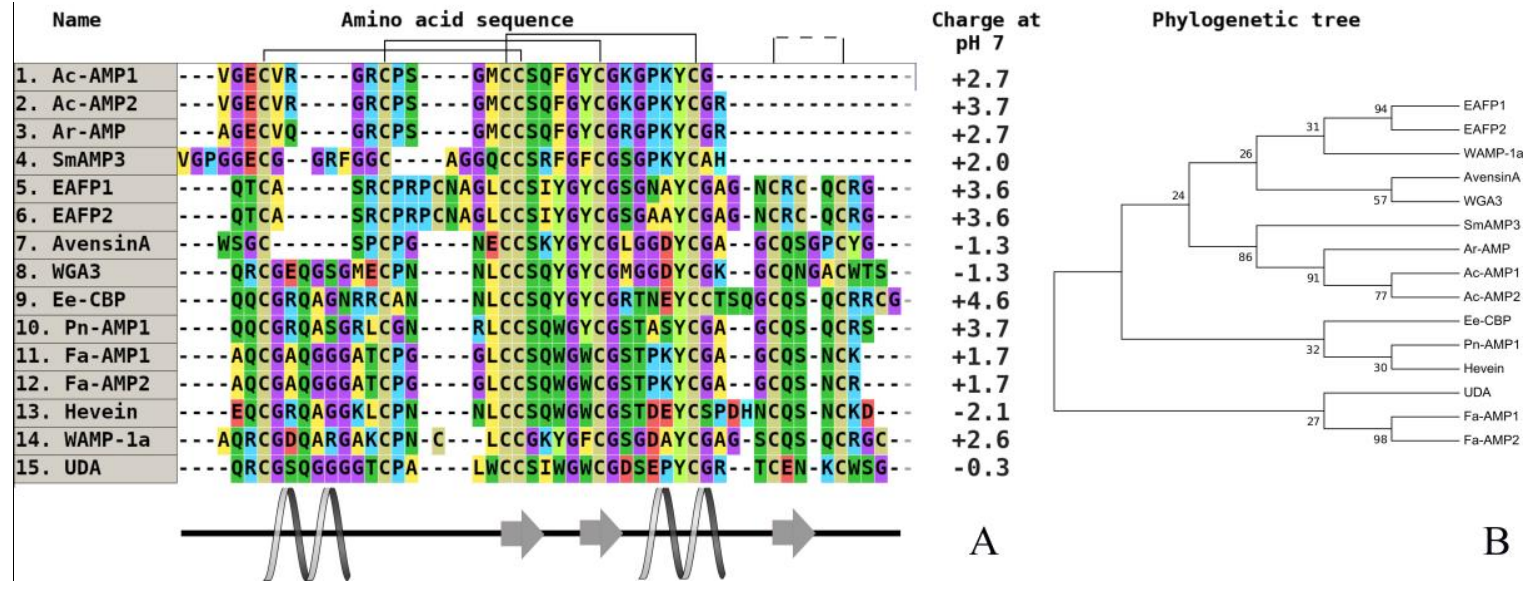

Figure 4. The alignment (A) and phylogenetic tree (B) of plant hevein-like peptides from six and 10-cysteine type subfamilies. Amino acids are highlighted in color, and conserved disulfide bonds are connected by black lines. Conservative elements of the secondary structure are shown under the alignment according to WAMP-1a from wheat (T. kiharae), (CP) [68]. Ac-AMP1-antimicrobial peptide 1 from Amaranthus caudatus (dicotyledons, GenBank ID: AAB22103), (CP); Ac-AMP2—antimicrobial peptide 2 from A. caudatus (dicotyledons, GenBank ID: AAB22102), (CP); Ar-AMP—antimicrobial peptide from $A$. retroflexus (dicotyledons, GenBank ID: Q5I2B2), (WP); SmAMP3—antimicrobial peptide 3 from Stellaria media (dicotyledons, GenBank ID: COHJU5), (WP); EAFP1—antifungal peptide 1 from Eucommia ulmoides (dicotyledons, UniProt ID: P83596), (WP); EAFP2—antifungal peptide 2 from E. ulmoides (dicotyledons, UniProt ID: P83597), (WP); WGA3 - agglutinin isolectin 3 from T. aestivum (monocotyledons, UniProt ID: P10969), (CP); Ee-CBP-hevein-type antimicrobial peptide from Euonymus europaeus (dicotyledons, (CP); Pn-AMP1-antimicrobial peptide from Ipomoea nil (dicotyledons, UniProt ID: P81591), (WP); Fa-AMP1—antimicrobial peptide from Fagopyrum esculentum (dicotyledons, UniProt ID: P0DKH7), (CP); Fa-AMP2—antimicrobial peptide from F. esculentum (dicotyledons, UniProt ID: P0DKH8), (CP); hevein-hevein from Hevea brasiliensis (dicotyledons, GenBank ID: AAA33357), (CP); WAMP-1a-antimicrobial peptide from T. kiharae (monocotyledons, PDB ID: 2LB7_A), (CP); UDA—agglutinin from Urtica dioica (dicotyledons, UniProt ID: P11218), (WP). All structures are marked: $\mathrm{CP}$ —cultivated plant species, $\mathrm{WP}$-wild plant species.

These AMPs are highly homologous, but a single amino acid substitution in the chitin-binding domain is critical for the level of antifungal activity, which does not correlate with fungalysin inhibition $[82,83]$. High antifungal activity was detected in all of the studied hevein-like plant peptides, but it was preliminary found in dicots. Their antimicrobial spectrum is sufficiently broad and includes the inhibition of filamentous and yeast-like microorganisms at a mean concentration of $10 \mu \mathrm{g} / \mathrm{mL}$ [84]. The WAMP-1a peptide can affect both Gram-positive and Gram-negative bacteria. After a more detailed examination of the data on the degree of antifungal activity in vitro (Table 2) for all of the currently known hevein-like peptides of cereals, we can say that the determining factor in this regard is the structure of the chitin-binding domain, in particular, amino acid residues, not directly involved in intermolecular interaction with the polymer. 
Table 2. Antifungal activity of some known hevein-like peptides from cereals $\left(\mathrm{IC}_{50}, \mu \mathrm{M}\right)$.

\begin{tabular}{|c|c|c|c|c|c|c|c|}
\hline Peptide/Microbe & $\begin{array}{l}\text { WAMP1a } \\
(+R)\end{array}$ & $\begin{array}{l}\text { WAMP1b } \\
(-R)\end{array}$ & $\begin{array}{l}\text { WAMP2a } \\
\text { (A34K) }\end{array}$ & $\begin{array}{c}\text { WAMP3a } \\
\text { (A34E) }\end{array}$ & $\begin{array}{c}\text { WAMP4a } \\
\text { (A34N) }\end{array}$ & LAMP-1a & Ar-AMP \\
\hline Bipolaris sorokiniana & 3.2 & 5.0 & Not tested & Not tested & Not tested & 5.6 & 32.0 \\
\hline Botrytis cinerea & Not tested & 20.0 & Not tested & Not tested & Not tested & Not tested & 32.0 \\
\hline Fusarium oxysporum & 3.9 & 5.0 & 4.0 & 7.6 & 7.0 & 6.0 & Not tested \\
\hline F. solani & Not tested & 5.0 & Not tested & Not tested & Not tested & Not tested & Not tested \\
\hline F. verticillioides & 1.9 & 2.7 & 2.2 & 3.5 & 3.0 & 4.5 & Not tested \\
\hline Neurospora crassa & Not tested & 10.0 & Not tested & Not tested & Not tested & Not tested & Not tested \\
\hline
\end{tabular}

As we noted earlier, the only amino acid variable replacement in the structure of the WAMP family peptides has a significant effect on their functionality, which is also confirmed by comparison with the amino acid sequence of the antimicrobial peptide LAMP-1a from wild-grown plant lyme grass (L. arenarius). Additionally, the presence of the last arginine residue in the WAMP sequence compensates for a positive charge in the C-terminal fragment of the molecule and increases the binding to chitin. Accordingly, it is not possible to draw conclusions about the differences in the level of activity between the peptides of cultivated and wild cereals based on the example of peptides from this family (including a small size of sample).

The members of both subfamilies typically have a long chitin-binding domain that functions at the initial stage of interaction with chitin from fungal cell walls. For example, one of these mechanisms is most likely responsible for the ability of WAMP peptides to inhibit the hydrolytic activity of the zinc metalloproteinase fungalysin (that is produced and secreted by the plant pathogenic fungus Fusarium verticillioides in infection) and reduce the inactivation of the catalytic domain of corn chitinase IV type [85]. There is not enough information about the structural diversity of peptides from this family to understand the differences between their contribution to the different resistances of wild and cultivated cereals. The data indicate that the high diversity of homologous genes encoding these molecules among a wide range of species from the Poaceae family (wild and cultivated) may broaden their ability to be activated under the action of signal molecules and heavy metals in plants [86].

Hairpin-like peptides (alpha-hairpinins) are a family of defense molecules of plant immunity, which were found and described relatively recently. They include short alpha-helical peptides with four cysteine residues that form two disulfide bridges, generating a beta-hairpin between alpha helices. The four-cysteine maize basic peptide (MBP-1) isolated from Z. mays kernels in 1992 was the first described member of these polypeptides. It exhibited high antimicrobial activity against some fungi, specific corn pathogens, and Gram-negative bacteria [87]. Peptides with an analogous structure were detected in dicotyledonous plants: nut (Macadamia integrifolia), buckwheat (Fagopyrum esculentum), winterweed (Veronica hederifolia), pumpkin (Cucurbita maxima), loofah (Luffa aegyptiaca), and chickweed (S. media) [16,88-93]. Two of them were found to be trypsin inhibitors (VhTI peptide from winterweed (V. herdefolia) and BWI-2c from buckwheat (F. esculentum)) [92,93]. The spatial structure of alpha-hairpinins' molecular complex with trypsin was determined by X-ray diffraction [92]. For the first time in wild cereals since the description of MBP-1, a novel family of antimicrobial hairpin-like peptides (EcAMPs) was discovered in barnyard grass (E. crusgalli) [94-96], as well as in the sequel that was also in cultivated wheat (T. kiharae) [97]. Studying the biological activity mechanisms of these peptides at the cellular level allowed us to conclude about their fungistatic influence on microscopic fungi, which was implemented as a delay in the spore germination and growth power of hyphae $[94,98]$. The data on the quantitative antifungal activity of some hairpin-like peptides are presented in Table 3.

The data presented demonstrates that isolated AMPs influence different fungus species in a broad range of active concentrations. It is characteristic that according to the results of comparative testing of biological activity in vitro, in general, certain experimentally found quantitative levels of antifungal effect of alpha-harpinins isolated from grain crops are less expressed than the level of their homologues from wild species, including dicots. 
These results may be explained by some fungi being able to cause diseases in many plant species, including cereals, whereas some other filamentous fungus are represented as having a too-narrow specificity toward cereals.

Table 3. Antifungal activity of some known alpha-hairpinins $\left(\mathrm{IC}_{50}, \mu \mathrm{M}\right)$.

\begin{tabular}{cccccccc}
\hline Peptide/Microbe & EcAMP1 & EcAMP2 & EcAMP3 & Tk-AMP-X1 & Tk-AMP-X2 & MBP-1 & Sm-AMP-X \\
\hline Alternaria alternata & 16.0 & $>32.0$ & 19.8 & Not tested & 28.8 & Not tested & 14.8 \\
Aspergillus niger & $>32.0$ & $>32.0$ & 22.4 & Not tested & $>32.0$ & Not tested & 4.0 \\
B. sorokiniana & 18.2 & $>32.0$ & 15.0 & Not tested & Not tested & Not tested & $>32.0$ \\
C. graminicola & $>10$ & Not tested & Not tested & $>30.0$ & $>30.0$ & Not tested & Not tested \\
D. maydis & $>10$ & Not tested & Not tested & 30.0 & 17.0 & Not tested & Not tested \\
F. graminearum & 4.5 & $>32.0$ & 5.5 & 7.5 & 7.5 & 4.0 & Not tested \\
F. oxysporum & 8.8 & $>32.0$ & 9.6 & Not tested & 13.5 & Not tested & 6.8 \\
F. solani & 4.0 & $>32.0$ & 4.8 & Not tested & 8.5 & Not tested & 8.0 \\
F. verticillioides & 8.1 & $>32.0$ & 5.2 & 15.0 & 10.0 & Not tested & Not tested \\
P. infestans & 16.3 & $>32.0$ & 14.0 & Not tested & 25.4 & Not tested & $>32.0$ \\
P. ultimum & 14.4 & Not tested & Not tested & Not tested & Not tested & Not tested & $>32.0$ \\
\hline
\end{tabular}

The multiple alignment of amino acid sequences of alpha-hairpinins isolated from plant organs, including cultivated and wild cereal species, reveals a stable low percentage of homology between them. The only exception is a pair of MBP-1 and EcAMP1 from corn and barnyard grass, which are highly homologous. Our experiments and the literature data allowed us to identify a fragment of the polypeptide chain of plant alpha-hairpinins that is critical for their biological activity. This is a secondary structure element, a beta-hairpin, that connects two alpha-helices and is about 10-13 amino acid residues in length (Figure 5).
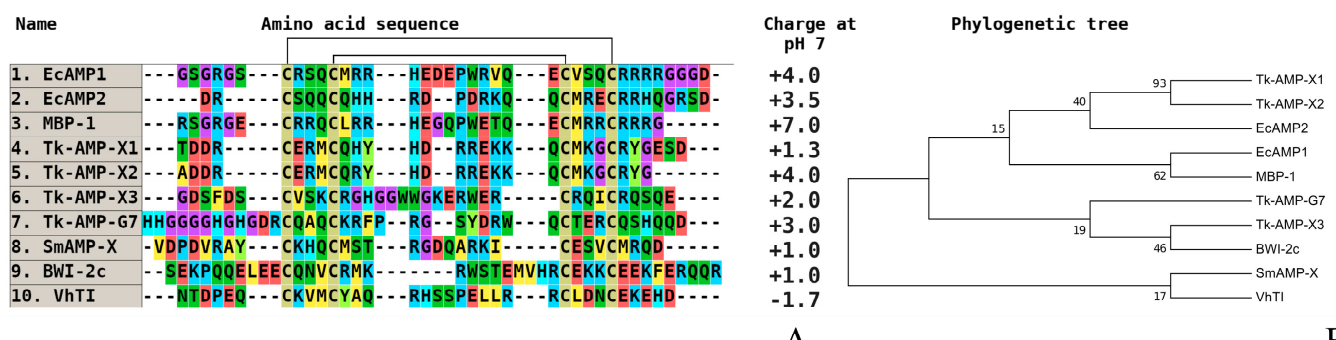

Figure 5. The alignment (A) and phylogenetic tree (B) of plant hairpin-like peptides. Amino acids are highlighted in color, and conserved disulfide bonds are connected by black lines. EcAMP1-antimicrobial peptide 1 from E. crusgalli (monocotyledons, GenBank ID: B3EWR6); EcAMP2—antimicrobial peptide 2 from E. crusgalli (GenBank ID: B3EWR6); MBP-1—antimicrobial peptide from Z. mays (monocotyledons, GenBank ID: AAB23306); Tk-AMP-X1—antimicrobial peptide X1 from T. kiharae (monocotyledons, [88]); Tk-AMP-X2-antimicrobial peptide X2 from T. kiharae [97]; Tk-AMP-X3-antimicrobial peptide X3 from T. kiharae [97]; Tk-AMP-G7-antimicrobial peptide G7 from T. kiharae [97]; SmAMP-X-antimicrobial peptide from S. media (dicotyledons, GenBank ID: U4N938); BWI-2c—-trypsin inhibitor 2c from F. esculentum (dicotyledons, UniProt ID: P86794); VhTI-trypsin inhibitor from Veronica hederifolia (dicotyledons, UniProt ID: P85981).

Based on the detailed analysis of amino acid sequences of hairpin fragments in alpha-hairpinins, we may draw conclusions about the higher antifungal activity and greater specificity of peptides from wild cereals compared to peptides from wheat and corn. These parameters may result from the presence of a mini cluster of positively charged amino acid residues (for effective interaction with negatively charged carbohydrate components of the superficial layer of fungal cell walls and any polymers, such as beta-1,3-glucans) [99]. Concerning the localization of the hairpin-like peptides from cereals and dicotyledonous plants, we can see that it also repeats the low homology of the molecules based on primary structure analysis. So, EcAMP1/2 is not similar to Tk-AMP-X1/2; rather, it is opposed to them, as they really contrast on antifungal activity. 
Furthermore, at least one hydrophobic residue (e.g., tryptophan) is responsible for binding to components of fungal cell membranes (e.g., sphingolipids or ergosterols) $[34,35]$.

\section{Conclusions}

This review for the first time provides a comparative analysis of the primary structures of AMPs from the most represented families of cultural and wild cereals' seeds. These peptides were analyzed to identify differences in their amino acid sequences. Due those differences, significant variations in the level of antimicrobial activity in relation to both the pathogens of specific fungal diseases of cereals, and pathogens with a wide range of host plants, are observed. For this analysis, we selected AMPs that belong to both the most studied families (defensins, thionins, and hevein-like peptides), and the poorly studied families (alpha-hairpinins, of hairpin-like peptides). As a result of the analysis, a large rate of variability of C-terminal fragments for peptides from the defensin family was detected. It should be noted that for representatives of wild forms of cereals, the presence of hydrophobic amino acid residues in those fragments is more intrinsic. We analyzed the similarity of various physicochemical parameters between thionins and defensins. The presence of highly pronounced divergence on a fixed part of any polypeptide that is close to defensins could be a determining factor. For all of the currently known hevein-like peptides of cereals, we can say that the determining factor in this regard is the structure of the chitin-binding domain, and in particular, amino acid residues that are not directly involved in intermolecular interaction with the polymer. The analysis of amino acid sequences of alpha-hairpinins revealed that the more significant quantitative antifungal activity and wide specificity of the peptides from wild cereals compared to those in the peptides from wheat and corn may be associated with parameters such as the presence of a mini cluster of positively charged amino acid residues and at least one hydrophobic residue that is responsible for binding to the components of fungal cell membranes. The conclusion indicates the possibility of using highly active AMPs of wild species of cereals as a basis for the creation of transgenic cultivated plants (including cereals) that express genes, coding AMPs. In addition, the application of genome-editing techniques for the promoters of target genes, coding potentially active AMPs in cultural cereals, may significantly increase their expression, which can also lead to a decrease in susceptibility to diseases.

Author Contributions: E.R. has created an idea of this review, generated the main text and provided a partial funding; D.R. corrected the text and made all figures and tables; A.S. was assigned in vitro testing of antifungal activity of the AMPs and explanations of the results received; S.Z. has provided funding and manuscript writing.

Funding: This research was funded by the Russian Science Foundation (grant number 14-50-00131 ) (section "Investigation of structural determinants from other AMPs (thionins, hevein-like peptides, and alpha-hairpinins), which provide higher antifungal activity to wild cereals"), the Russian Foundation for Basic Research (grant number 16-34-60217_mol_a_dk (section "Comparative analysis of the primary structure of defensins isolated from wild and cultivated cereals") and the APC was funded by the Russian Science Foundation (grant number 14-50-00131).

Acknowledgments: We also thank to Tatyana I. Odintsova (Vavilov Institute of General Genetics of the Russian Academy of Sciences) for long-standing collaboration in studying antimicrobial peptides from cereals.

Conflicts of Interest: The authors declare no conflict of interests.

\section{References}

1. Cheng, F.; Cheng, Z. Research Progress on the use of Plant Allelopathy in Agriculture and the Physiological and Ecological Mechanisms of Allelopathy. Front. Plant Sci. 2015, 6, 1020. [CrossRef] [PubMed]

2. Shah, A.N.; Iqbal, J.; Ullah, A.; Yang, G.; Yousaf, M.; Fahad, S.; Tanveer, M.; Hassan, W.; Tung, S.A.; Wang, L.; et al. Allelopathic potential of oil seed crops in production of crops: A review. Environ. Sci. Pollut. Res. Int. 2016, 15, 14854-14867. [CrossRef] [PubMed]

3. Hanin, M.; Ebel, C.; Ngom, M.; Laplaze, L.; Masmoudi, K. New Insights on Plant Salt Tolerance Mechanisms and Their Potential Use for Breeding. Front. Plant Sci. 2016, 7, 1787. [CrossRef] [PubMed]

4. Radhakrishnan, R.; Baek, K.H. Physiological and biochemical perspectives of non-salt tolerant plants during bacterial interaction against soil salinity. Plant Physiol. Biochem. 2017, 116, 116-126. [CrossRef] [PubMed] 
5. Suzuki, N.; Rivero, R.M.; Shulaev, V.; Blumwald, E.; Mittler, R. Abiotic and biotic stress combinations. New Phytol. 2014, 203, 32-43. [CrossRef] [PubMed]

6. Jha, U.C.; Bohra, A.; Jha, R. Breeding approaches and genomics technologies to increase crop yield under low-temperature stress. Plant Cell Rep. 2017, 36, 1-35. [CrossRef] [PubMed]

7. Mesihovic, A.; Iannacone, R.; Firon, N.; Fragkostefanakis, S. Heat stress regimes for the investigation of pollen thermotolerance in crop plants. Plant Reprod. 2016, 29, 93-105. [CrossRef] [PubMed]

8. Abdelrahman, M.; El-Sayed, M.; Jogaiah, S.; Burrit, D.J.; Tran, L.P. The "STAY-GREEN" trait and phytohormone signaling networks in plants under heat stress. Plant Cell Rep. 2017, 36, 1009-1025. [CrossRef] [PubMed]

9. de Souza Cândido, E.; Sousa, D.A.; Viana, J.C.; de Oliveira-Júnior, N.G.; Miranda, V.; Franco, O.L. The use of versatile plant antimicrobial peptides in agribusiness and human health. Peptides 2014, 55, 65-78. [CrossRef] [PubMed]

10. Yan, J.; Yuan, S.S.; Jiang, L.L.; Ye, X.J.; Ng, T.B.; Wu, Z.J. Plant antifungal proteins and their applications in agriculture. Appl. Microbiol. Biotechnol. 2015, 99, 4961-4981. [CrossRef] [PubMed]

11. Tam, J.P.; Wang, S.; Wong, K.H.; Tan, W.L. Antimicrobial Peptides from Plants. Pharmaceuticals 2015, 8, 711-757. [CrossRef] [PubMed]

12. Tang, S.S.; Prodhan, Z.H.; Biswas, S.K.; Le, C.F.; Sekaran, S.D. Antimicrobial peptides from different plant sources: Isolation, characterisation, and purification. Phytochemistry 2018, 154, 94-105. [CrossRef] [PubMed]

13. Sels, J.; Mathys, J.; De Coninck, B.M.; Cammue, B.P.; De Bolle, M.F. Plant pathogenesis-related (PR) proteins: A focus on PR peptides. Plant Physiol. Biochem. 2008, 46, 941-950. [CrossRef] [PubMed]

14. Wang, W.M.; Liu, P.Q.; Xu, Y.J.; Xiao, S. Protein trafficking during plant innate immunity. J. Integr. Plant Biol. 2016, 58, 284-298. [CrossRef] [PubMed]

15. Andreev, Y.A.; Korostyleva, T.V.; Slavokhotova, A.A.; Rogozhin, E.A.; Utkina, L.L.; Vassilevski, A.A.; Grishin, E.V.; Egorov, T.A.; Odintsova, T.I. Genes encoding hevein-like defense peptides in wheat: Distribution, evolution, and role in stress response. Biochimie 2012, 94, 1009-1016. [CrossRef] [PubMed]

16. Slavokhotova, A.A.; Rogozhin, E.A.; Musolyamov, A.K.; Andreev, Y.A.; Oparin, P.B.; Berkut, A.A.; Vassilevski, A.A.; Egorov, T.A.; Grishin, E.V.; Odintsova, T.I. Novel antifungal $\alpha$-hairpinin peptide from Stellaria media seeds: Structure, biosynthesis, gene structure and evolution. Plant Mol. Biol. 2014, 84, 189-202. [CrossRef] [PubMed]

17. Lobo, D.S.; Pereira, I.B.; Fragel-Madeira, L.; Medeiros, L.N.; Cabral, L.M.; Faria, J.; Bellio, M.; Campos, R.C.; Linden, R.; Kurtenbach, E. Antifungal Pisum sativum defensin 1 interacts with Neurospora crassa cyclin F related to the cell cycle. Biochemistry 2007, 46, 987-996. [CrossRef] [PubMed]

18. Graham, M.A.; Silverstein, K.A.; Cannon, S.B.; VandenBosch, K.A. Computational identification and characterization of novel genes from legumes. Plant Physiol. 2004, 135, 1179-1197. [CrossRef] [PubMed]

19. Kristensen, A.K.; Brunstedt, J.; Nielsen, J.E.; Mikkelsen, J.D.; Roepstorff, P.; Nielsen, K.K. Processing, disulfide pattern, and biological activity of a sugar beet defensin, AX2, expressed in Pichia pastoris. Protein Exp. Purif. 1999, 16, 377-387. [CrossRef] [PubMed]

20. de Zélicourt, A.; Letousey, P.; Thoiron, S.; Campion, C.; Simoneau, P.; Elmorjani, K.; Marion, D.; Simier, P.; Delavault, P. Ha-DEF1, a sunflower defensin, induces cell death in Orobanche parasitic plants. Planta 2007, 226, 591-600. [CrossRef] [PubMed]

21. Do, H.M.; Lee, S.C.; Jung, H.W.; Sohn, K.H.; Hwang, B.K. Differential expression and in sutu localization of a pepper defensin (CADEF1) gene in response to pathogen infection, abiotic elicitors and environmental stresses in Capsicum anuum. Plant Sci. 2004, 166, 1297-1305.

22. Fujiumura, M.; Ideguchi, M.; Minami, Y.; Watanabe, K.; Tadera, K. Purification, characterization and sequencing of novel antimicrobial peptides Tu-AMP1 and Tu-AMP2 from bulbs of tulip (Tulipa gesneriana L.). Biosci. Biotechnol. Biochem. 2004, 63, 571-577. [CrossRef] [PubMed]

23. Wisniewski, M.E.; Bassett, C.L.; Artlip, T.S.; Webb, R.P.; Janisiewicz, W.J.; Norelli, J.L. Characterization of a defensin from bark and fruit tissues of peach and antimicrobial activity of a recombinant defensin in the yeast, Pichia pastoris. Physiol. Plant. 2003, 119, 563-572. [CrossRef]

24. Bloch, C.J.; Richardson, M.A. A new family of small (5 kDa) protein inhibitors of insect $\alpha$-amylases from seeds of sorghum (Sorghum bicolor (L.) Moebch.) have sequence homologies with wheat $\gamma$-purothionins. FEBS J. 1991, 279, 101-104. [CrossRef] 
25. Mendez, E.; Moreno, A.; Colilla, F.; Pelaez, F.; Limas, G.G.; Mendez, R. Primary structure and inhibition of protein synthesis in eukaryotic cell-free system of a novel thionin, $\gamma$-hordothionin, from barley endosperm. Eur. J. Biochem. 1990, 194, 533-539. [CrossRef] [PubMed]

26. Mendez, E.; Rocher, A.; Calero, M.; Girbes, T.; Citores, L.; Soriano, F. Primary structure of $\omega$-hordothionin, a member of a novel family of thionins from barley endosperm, and its inhibition of protein synthesis in eukaryotic and prokaryotic cell-free systems. Eur. J. Biochem. 1996, 239, 67-73. [CrossRef] [PubMed]

27. Segura, A.; Moreno, M.; Molina, A.; Garcia-Olmedo, F. Novel defensin subfamily from spinach (Spinacea oleracea). FEBS Lett. 1998, 435, 159-162. [CrossRef]

28. Sharma, P.; Lönneborg, A. Isolation and characterization of a cDNA encoding a plant defensin-like protein from roots of Norway spruce. Plant Mol. Biol. 1996, 31, 707-712. [CrossRef] [PubMed]

29. Li, D.-H.; Jian, G.-L.; Zhang, Y.-T.; Ai, T.-M. Bacterial expression of a Trichosanthes lirilowii defensin (TDEF1) and its antifungal activity on Fusarium oxysporum. Appl. Microbiol. Biotechnol. 2007, 28, 62-75.

30. Colilla, F.J.; Rocher, A.; Mendez, E. Gamma-purothionins: Amino acid sequence of two polypeptides of a new family of thionins from wheat endosperm. FEBS Lett. 1990, 270, 191-194. [CrossRef]

31. Vriens, K.; Cammue, B.P.; Thevissen, K. Antifungal plant defensins: Mechanisms of action and production. Molecules 2014, 19, 12280-12303. [CrossRef] [PubMed]

32. Broekaert, W.F.; Terras, F.R.G.; Cammue, B.P.; Osborn, R.W. Plant defensins: Novel antimicrobial peptides as components of the host defense system. Plant Physiol. 1995, 108, 1353-1358. [CrossRef] [PubMed]

33. Lacerda, A.F.; Vasconcelos, E.A.; Pelegrini, P.B.; Grossi de Sa, M.F. Antifungal defensins and their role in plant defense. Front. Microbiol. 2014, 5, 116. [CrossRef] [PubMed]

34. Thevissen, K.; Ferket, K.K.; François, I.E.; Cammue, B.P. Interactions of antifungal plant defensins with fungal membrane components. Peptides 2003, 24, 1705-1712. [CrossRef] [PubMed]

35. Thevissen, K.; Warnecke, D.C.; François, I.E.; Leipelt, M.; Heinz, E.; Ott, C.; Zähringer, U.; Thomma, B.P.; Ferket, K.K.; Cammue, B.P. Defensins from insects and plants interact with fungal glucosylceramides. J. Biol. Chem. 2004, 279, 3900-3905. [CrossRef] [PubMed]

36. Egorov, T.A.; Odintsova, T.I.; Pukhalsky, V.A.; Grishin, E.V. Diversity of wheat antimicrobial peptides. Peptides 2005, 26, 2064-2073. [CrossRef] [PubMed]

37. Odintsova, T.I.; Egorov, T.A.; Musolyamov, A.K.; Odintsova, M.S.; Pukhalsky, V.A.; Grishin, E.V. Seed defensins from T. kiharae and related species: Genome localization of defensin-encoding genes. Biochimie 2007, 89, 605-612. [PubMed]

38. Odintsova, T.I.; Rogozhin, E.A.; Baranov, Y.; Musolyamov, A.K.; Yalpani, N.; Egorov, T.A.; Grishin, E.V. Seed defensins of barnyard grass Echinochloa crusgalli (L.) Beauv. Biochimie 2008, 90, 1667-1673. [CrossRef] [PubMed]

39. Osborn, R.W.; De Samblanx, G.W.; Thevissen, K.; Goderis, I.; Torrekens, S.; Van Leuven, F. Isolation and characterization of plant defensins from seeds of Asteraceae, Fabaceae, Hippocastanaceae and Saxifragaceae. FEBS Lett. 1995, 368, 257-262. [CrossRef]

40. Terras, F.R.G.; Schofs, H.M.E.; de Bolle, M.F.C.; Van Leuven, F.; Rees, S.B. In vitro antifungal activity of a radish (Raphanus sativus L.) seed protein homologous to nonspecific lipid lipid transfer proteins. Plant Physiol. 1992, 100, 1055-1058. [CrossRef] [PubMed]

41. De Samblanx, G.W.; Goderis, I.J.; Thevissen, K.; Raemaekers, R.; Fant, F.; Borremans, F.; Acland, D.P.; Osborn, R.W.; Patel, S.; Broekaert, W.F. Mutational analysis of a plant defensin from radish (Raphanus sativus L.) reveals two adjacent sites important for antifungal activity. J. Biol. Chem. 1997, 272, 1171-1179. [CrossRef] [PubMed]

42. Wu, J.; Jin, X.; Zhao, Y.; Dong, Q.; Jiang, H.; Ma, Q. Evolution of the defensin-like gene family in grass genomes. J. Genet. 2016, 95, 53-62. [CrossRef] [PubMed]

43. Slavokhotova, A.A.; Shelenkov, A.A.; Odintsova, T.I. Prediction of Leymus arenarius (L.) antimicrobial peptides based on de novo transcriptome assembly. Plant Mol. Biol. 2015, 89, 203-214. [CrossRef] [PubMed]

44. Matić, S.; Bagnaresi, P.; Biselli, C.; Orru', L.; Amaral Carneiro, G.; Siciliano, I.; Valé, G.; Gullino, M.L.; Spadaro, D. Comparative transcriptome profiling of resistant and susceptible rice genotypes in response to the seedborne pathogen Fusarium fujikuroi. BMC Genomics 2016, 17, 608. [CrossRef] [PubMed]

45. Haddadi, P.; Ma, L.; Wang, H.; Borhan, M.H. Genome-wide transcriptomic analyses provide insights into the lifestyle transition and effector repertoire of Leptosphaeria maculans during the colonization of Brassica napus seedlings. Mol. Plant Pathol. 2016, 17, 1196-1210. [CrossRef] [PubMed] 
46. Gordon, C.S.; Rajagopalan, N.; Risseeuw, E.P.; Surpin, M.; Ball, F.J.; Barber, C.J.; Buhrow, L.M.; Clark, S.M.; Page, J.E.; Todd, C.D.; et al. Characterization of Triticum aestivum Abscisic Acid Receptors and a Possible Role for These in Mediating Fusairum Head Blight Susceptibility in Wheat. PLoS ONE 2016, 11, e0164996. [CrossRef] [PubMed]

47. Slavokhotova, A.A.; Shelenkov, A.A.; Korostyleva, T.V.; Rogozhin, E.A.; Melnikova, N.V.; Kudryavtseva, A.V.; Odintsova, T.I. Defense peptide repertoire of Stellaria media predicted by high throughput next generation sequencing. Biochimie 2017, 135, 15-27. [CrossRef] [PubMed]

48. Romero, A.; Alamillo, J.M.; Garcia-Olmedo, F. Processing of thionin precursors in barley leaves by a vacuolar proteinase. Eur. J. Biochem. 1997, 243, 202-208. [CrossRef] [PubMed]

49. Florack, D.E.; Stiekema, W.J. Thionins: Properties, possible biological roles and mechanisms of action. Plant Mol. Biol. 1994, 26, 25-37. [CrossRef] [PubMed]

50. García-Olmedo, F.; Molina, A.; Alamillo, J.M.; Rodríguez-Palenzuéla, P. Plant defense peptides. Biopolymers 1998, 47, 479-491. [CrossRef]

51. Bruix, M.; Jiménez, M.A.; Santoro, J.; González, C.; Colilla, F.J.; Méndez, E.; Rico, M. Solution structure of gamma 1-H and gamma 1-P thionins from barley and wheat endosperm determined by 1H-NMR: A structural motif common to toxic arthropod proteins. Biochemistry 1993, 32, 715-724. [CrossRef] [PubMed]

52. Stec, B.; Rao, U.; Teeter, M.M. Refinement of purothionins reveals solute particles important for lattice formation and toxicity. Part 2: Structure of beta-purothionin at 1.7 A resolution. Acta Crystallogr. D Biol. Crystallogr. 1995, 51, 914-924. [CrossRef] [PubMed]

53. Johnson, K.A.; Kim, E.; Teeter, M.M.; Suh, S.W.; Stec, B. Crystal structure of alpha-hordothionin at 1.9 Angstrom resolution. FEBS Lett. 2005, 579, 2301-2306. [CrossRef] [PubMed]

54. Pal, A.; Debreczeni, J.E.; Sevvana, M.; Gruene, T.; Kahle, B.; Zeeck, A.; Sheldrick, G.M. Structures of viscotoxins A1 and B2 from European mistletoe solved using native data alone. Acta Crystallogr. D Biol. Crystallogr. 2008, 64, 985-992. [CrossRef] [PubMed]

55. Reimann-Philipp, U.; Schrader, G.; Martinoia, E.; Barkholt, V.; Apel, K. Intracellular thionins of barley. A second group of leaf thionins closely related to but distinct from cell wall-bound thionins. J. Biol. Chem. 1989, 264, 8978-8984. [PubMed]

56. Stec, B. Plant thionins-the structural perspective. Cell. Mol. Life Sci. 2006, 63, 1370-1385. [CrossRef] [PubMed]

57. Ji, H.; Gheysen, G.; Ullah, C.; Verbeek, R.; Shang, C.; Vleesschauwer, D.D.; Höfte, M.; Kyndt, T. The role of thionins in rice defence against root pathogens. Mol. Plant Pathol. 2015, 16, 870-881. [CrossRef] [PubMed]

58. Zasukhina, G.D.; Odintsova, T.I.; Shulenina, L.V.; Ushenkova, L.N.; Mikhailov, V.F.; Shagirova, Z.M.; Vedernikov, A.N.; Gromov, S.P.; Alfimov, M.V. Antimutagens ( $\beta$-purothionin and crown compound) as modulators of expression of genes involved in carcinogenesis in human cells. Dokl. Biochem. Biophys. 2012, 446, 254-256. [CrossRef] [PubMed]

59. Zasukhina, G.D.; Vasilyeva, I.M.; Kadnikov, I.A.; Voronin, M.V.; Odintsova, T.I.; Korostileva, T.V.; Pukhalskii, V.A. Antimutagenic activity of wheat polypeptides in human cells exposed to cadmium chloride. Bull. Exp. Biol. Med. 2013, 155, 370-372. [CrossRef] [PubMed]

60. Zasukhina, G.D.; Shagirova, J.M.; Babintsev, M.V.; Vasilyeva, I.M.; Rogozhin, E.A.; Odintsova, T.I.; Mikhailov, V.F.; Gromov, S.P.; Vedernikov, A.I.; Alfimov, M.V. Modulation of gene expression by antimutagens in human cells differing in the sensitivity to mutagens. Dokl. Biochem. Biophys. 2013, 453, 277-279. [CrossRef] [PubMed]

61. Odintsova, T.I.; Vasil'eva, I.M.; Korostyleva, T.V.; Utkina, L.L.; Slavokhotova, A.A.; Rogozhin, E.A.; Shiian, A.N.; Pukhal'skiǔ, V.A.; Zasukhina, G.D. Antimutagenic activity of wheat beta-purothionin Tk-AMP-BP. Russ. J. Genet. 2011, 47, 1267-1270. [CrossRef]

62. Pelegrini, P.B.; Franco, O.L. Plant gamma-thionins: Novel insights on the mechanism of action of a multi-functional class of defense proteins. Int. J. Biochem. Cell. Biol. 2005, 37, 2239-2253. [CrossRef] [PubMed]

63. Mikhailov, V.F.; Shishkina, A.A.; Vasilyeva, I.M.; Shulenina, L.V.; Raeva, N.F.; Rogozhin, E.A.; Startsev, M.I.; Zasukhina, G.D.; Gromov, S.P.; Alfimov, M.V. Comparative analysis of natural and synthetic antimutagens as regulators of gene expression in human cells under exposure to ionizing radiation. Russ. J. Genet. 2015, 51, 147-155. [CrossRef]

64. Kul'ko, A.B.; Kisil', O.V.; Sadykova, V.S.; Mikhailov, V.F.; Vasilyeva, I.M.; Shulenina, L.V.; Zasukhina, G.D.; Rogozhin, E.A. Investigation of thionins from blackseed (Nigella sativa L.) possess cytotoxic, regulatory and antifungal activity. Antibiotiki I khimioterapiya 2016, 61, 8-16. (In Russian) 
65. Vasilchenko, A.S.; Smirnov, A.N.; Zavriev, S.K.; Grishin, E.V.; Vasilchenko, A.V.; Rogozhin, E.A. Novel thionins from black seed (Nigella sativa L.) demonstrate antimicrobial activity. Int. J. Pept. Res. Ther. 2017, 23, 171-180. [CrossRef]

66. Giudici, A.M.; Regente, M.C.; Villalaín, J.; Pfüller, K.; Pfüller, U.; De La Canal, L. Mistletoe viscotoxins induce membrane permeabilization and spore death in phytopathogenic fungi. Physiol. Plant. 2004, 121, 2-7. [CrossRef] [PubMed]

67. Guzmán-Rodríguez, J.J.; Ochoa-Zarzosa, A.; López-Gómez, R.; López-Meza, J.E. Plant antimicrobial peptides as potential anticancer agents. Biomed. Res. Int. 2015, 2015, 735087. [CrossRef] [PubMed]

68. Teeter, M.M.; Ma, X.Q.; Rao, U.; Whitlow, M. Crystal structure of a protein-toxin alpha 1-purothionin at 2.5A and a comparison with predicted models. Proteins 1990, 8, 118-132. [CrossRef] [PubMed]

69. Loeza-Ángeles, H.; Sagrero-Cisneros, E.; Lara-Zárate, L.; Villagómes-Gómez, E.; López-Meza, J.E.; Ochoa-Zarzosa, A. Thionin Thi2.1 from Arabidopsis thaliana expressed in endothelial cells shows antibacterial, antifungal and cytotoxic activity. Biotechnol. Lett. 2008, 10, 1713-1719. [CrossRef] [PubMed]

70. Van Parijs, J.W.F.; Broekaert, J.; Goldstein, I.J.; Peumans, W.J. Hevein: An antifungal protein from rubber-tree (Hevea brasiliensis) latex. Planta 1991, 183, 258-264. [CrossRef] [PubMed]

71. Raikhel, N.V.; Lee, H.-I. Structure and function of chitin-binding proteins. Annu. Rev. Plant Physiol. Plant Mol. Biol. 1993, 44, 591-615. [CrossRef]

72. Beintema, J.J. Structural features of plant chitinases and chitin-binding proteins. FEBS Lett. 1994, 350, $159-163$. [CrossRef]

73. De Bolle, M.F.; David, K.M.; Rees, S.B.; Vanderleyden, J.; Cammue, B.P.; Broekaert, W.F. Cloning and characterization of a cDNA encoding an antimicrobial chitin-binding protein from amaranth, Amaranthus caudatus. Plant Mol. Biol. 1993, 22, 1187-1190. [CrossRef] [PubMed]

74. Broekaert, W.F.; Mariën, W.; Terras, F.R.; De Bolle, M.F.; Proost, P.; Van Damme, J.; Dillen, L.; Claeys, M.; Rees, S.B.; Vanderleyden, J.; et al. Antimicrobial peptides from Amaranthus caudatus seeds with sequence homology to the cysteine/glycine-rich domain of chitin-binding proteins. Biochemistry 1992, 31, 4308-4314. [CrossRef] [PubMed]

75. Lipkin, A.; Anisimova, V.; Nikonorova, A.; Babakov, A.; Krause, E.; Bienert, M.; Grishin, E.; Egorov, T. An antimicrobial peptide Ar-AMP from amaranth (Amaranthus retroflexus L.) seeds. Phytochemistry 2005, 66, 2426-2431. [CrossRef] [PubMed]

76. Rogozhin, E.A.; Slezina, M.P.; Slavokhotova, A.A.; Istomina, E.A.; Korostyleva, T.V.; Smirnov, A.N.; Grishin, E.V.; Egorov, T.A.; Odintsova, T.I. A novel antifungal peptide from leaves of the weed Stellaria media L. Biochimie 2015, 116, 125-132. [CrossRef] [PubMed]

77. Komakhin, R.A.; Vysotskii, D.A.; Shukurov, R.R.; Voblikova, V.D.; Komakhina, V.V.; Strelnikova, S.R.; Vetchinkina, E.M.; Babakov, A.V. Novel strong promoter of antimicrobial peptides gene pro-SmAMP2 from chickweed (Stellaria media). BMC Biotechnol. 2016, 16, 43. [CrossRef] [PubMed]

78. Huang, R.H.; Xiang, Y.; Liu, X.Z.; Zhang, Y.; Hu, Z.; Wang, D.C. Two novel antifungal peptides distinct with a five-disulfide motif from the bark of Eucommia ulmoides Oliv. FEBS Lett. 2002, 521, 87-90. [CrossRef]

79. Odintsova, T.I.; Vassilevski, A.A.; Slavokhotova, A.A.; Musolyamov, A.Kh.; Finkina, E.I.; Khadeeva, N.V.; Rogozhin, E.A.; Korostyleva, T.V.; Pukhalsky, V.A.; Grishin, E.V.; et al. A novel antifungal hevein-type peptide from Triticum kiharae seeds with a unique 10-cysteine motif. FEBS J. 2009, 275, 4266-4275. [CrossRef] [PubMed]

80. Dubovskii, P.V.; Vassilevski, A.A.; Slavokhotova, A.A.; Odintsova, T.I.; Grishin, E.V.; Egorov, T.A.; Arseniev, A.S. Solution structure of a defense peptide from wheat with a 10-cysteine motif. Biochem. Biophys. Res. Commun. 2011, 411, 14-18. [CrossRef] [PubMed]

81. Utkina, L.L.; Zhabon, E.O.; Slavokhotova, A.A.; Rogozhin, E.A.; Shiian, A.N.; Grishin, E.V.; Egorov, T.A.; Odintsova, T.I.; Pukhal'skiǔ, V.A. Heterologous expression of a synthetic gene encoding a novel hevein-type antimicrobial peptide of Leymus arenarius in Escherichia coli cells. Russ. J. Genet. 2010, 46, 1645-1651. [CrossRef]

82. Naumann, T.A. Modification of recombinant maize ChitA chitinase by fungal chitinase-modifying proteins. Mol. Plant Pathol. 2011, 12, 365-372. [CrossRef] [PubMed]

83. Slavokhotova, A.A.; Shelenkov, A.A.; Andreev, Y.A.; Odintsova, T.I. Hevein-Like Antimicrobial Peptides of Plants. Biochemistry 2017, 82, 1659-1674. [CrossRef] [PubMed]

84. Naumann, T.A.; Wicklow, D.T.; Price, N.P. Identification of a chitinase-modifying protein from Fusarium verticillioides: Truncation of a host resistance protein by a fungalysin metalloprotease. J. Biol. Chem. 2011, 286, 35358-35366. [CrossRef] [PubMed] 
85. Slavokhotova, A.A.; Naumann, T.A.; Price, N.P.; Rogozhin, E.A.; Andreev, Y.A.; Vassilevski, A.A.; Odintsova, T.I. Novel mode of action of plant defense peptides-Hevein-like antimicrobial peptides from wheat inhibit fungal metalloproteases. FEBS J. 2014, 281, 4754-4764. [CrossRef] [PubMed]

86. Istomina, E.A.; Korostyleva, T.V.; Rozhnova, N.A.; Rogozhin, E.A.; Pukhalski, V.A.; Odintsova, T.I. Genes encoding hevein-like antimicrobial peptides WAMPs: Expression in response to phytohormones and environmental factors. Russ. J. Genet. 2016, 52, 1176-1185. [CrossRef]

87. Duvick, J.P.; Rood, T.; Rao, A.G.; Marshak, D.R. Purification and characterization of a novel antimicrobial peptide from maize (Zea mays L.) kernels. J. Biol. Chem. 1992, 267, 18814-18820. [PubMed]

88. Marcus, J.P.; Green, J.L.; Goulter, K.C.; Manners, J.M. A family of antimicrobial peptides is produced by processing of a 7S globulin protein in Macadamia integrifolia kernels. Plant J. 1999, 19, 699-710. [CrossRef] [PubMed]

89. Li, F.; Yang, X.X.; Xia, H.C.; Zeng, R.; Hu, W.G.; Li, Z.; Zhang, Z.C. Purification and characterization of Luffin P1, a ribosome-inactivating peptide from the seeds of Luffa cylindrical. Peptides 2003, 24, 799-805. [CrossRef]

90. Park, S.S.; Abe, K.; Kimura, M.; Urisu, A.; Yamasaki, N. Primary structure and allergenic activity of trypsin inhibitors from the seeds of buckwheat (Fagopyrum esculentum Moench). FEBS Lett. 1997, 400, 103-107. [CrossRef]

91. Yamada, K.; Shimada, T.; Kondo, M.; Nishimura, M.; Hara-Nishimura, I. Multiple functional proteins are produced by cleaving Asn-Gln bonds of a single precursor by vacuolar processing enzyme. J. Biol. Chem. 1999, 274, 2563-2570. [CrossRef] [PubMed]

92. Conners, R.; Konarev, A.V.; Forsyth, J.; Lovegrove, A.; Marsh, J.; Joseph-Horne, T.; Shewry, P.; Brady, R.L. An unusual helix-turn-helix protease inhibitory motif in a novel trypsin inhibitor from seeds of Veronica (Veronica hederifolia L.). J. Biol. Chem. 2007, 282, 27760-27768. [CrossRef] [PubMed]

93. Oparin, P.B.; Mineev, K.S.; Dunaevsky, Y.E.; Arseniev, A.S.; Belozersky, M.A.; Grishin, E.V.; Egorov, T.A.; Vassilevski, A.A. Buckwheat trypsin inhibitor with helical hairpin structure belongs to a new family of plant defence peptides. Biochem. J. 2012, 446, 69-77. [CrossRef] [PubMed]

94. Nolde, S.B.; Vassilevski, A.A.; Rogozhin, E.A.; Barinov, N.A.; Balashova, T.A.; Samsonova, O.V.; Baranov, Y.V.; Feofanov, A.V.; Egorov, T.A.; Arseniev, A.S.; et al. Disulfide-stabilized helical hairpin structure and activity of a novel antifungal peptide EcAMP1 from seeds of barnyard grass (Echinochloa crus-galli). J. Biol. Chem. 2011, 286, 25145-25153. [CrossRef] [PubMed]

95. Rogozhin, E.A.; Ryazantsev, D.Y.; Grishin, E.V.; Egorov, T.A.; Zavriev, S.K. Defense peptides from barnyard grass (Echinochloa crusgalli L.) seeds. Peptides 2012, 38, 33-40. [CrossRef] [PubMed]

96. Ryazantsev, D.Y.; Rogozhin, E.A.; Dimitrieva, T.V.; Drobyazina, P.E.; Khadeeva, N.V.; Egorov, T.A.; Grishin, E.V.; Zavriev, S.K. A novel hairpin-like antimicrobial peptide from barnyard grass (Echinochloa crusgalli L.) seeds: Structure-functional and molecular-genetics characterization. Biochimie 2014, 99, 63-70. [CrossRef] [PubMed]

97. Utkina, L.L.; Andreev, Y.A.; Rogozhin, E.A.; Korostyleva, T.V.; Slavokhotova, A.A.; Oparin, P.B.; Vassilevski, A.A.; Grishin, E.V.; Egorov, T.A.; Odintsova, T.I. Genes encoding 4-Cys antimicrobial peptides in wheat Triticum kiharae Dorof. et Migush.: Multimodular structural organization, instraspecific variability, distribution and role in defence. FEBS J. 2013, 280, 3594-3608. [CrossRef] [PubMed]

98. Vasilchenko, A.S.; Yuryev, M.; Ryazantsev, D.Y.; Zavriev, S.K.; Feofanov, A.V.; Grishin, E.V.; Rogozhin, E.A. Studying of cellular interaction of hairpin-like peptide EcAMP1 from barnyard grass (Echinochloa crusgalli L.) seeds with plant pathogenic fungus Fusarium solani using microscopy techniques. Scanning 2016, 38, 591-598. [CrossRef] [PubMed]

99. Van der Weerden, N.L.; Bleackley, M.R.; Anderson, M.A. Properties and mechanisms of action of naturally occurring antifungal peptides. Cell. Mol. Life Sci. 2013, 70, 3545-3570. [CrossRef] [PubMed]

(C) 2018 by the authors. Licensee MDPI, Basel, Switzerland. This article is an open access article distributed under the terms and conditions of the Creative Commons Attribution (CC BY) license (http:/ / creativecommons.org/licenses/by/4.0/). 